\title{
Desain Didaktis Bahan Ajar Matematika SMP Berbasis Learning Obstacle dan Learning Trajectory
}

\author{
Endang Dedy ${ }^{1}$, Encum Sumiaty ${ }^{\mathbf{2}}$ \\ ${ }^{1,2}$ Departemen Pendidikan Matematika FPMIPA UPI, \\ Jl. Dr. Setiabudhi No. 229 Bandung
}

\begin{abstract}
This study is to correct mathematical learning by didactic design based on learning obstacles and learning trajectory. This is a qualitative study through Didactical Design Research (DDR) by three analytical phase, i.e. 1) didactical situation analysis before learning presented as didactical design hypothesis including ADP; 2) metapedadidactical analysis which analyze teacher's ability such as unity, flexibility, and coherency in learning; 3) retrospective analysis which is the correlated analysis between the result of didactical situation hypothesis analysis and metapedadidactical analysis. Result of problem analysis related to integer arithmetic operation, concept of function, and two triangle similarity concept, implementation of early didactical design could predict probable mistakes done by students and even if the mistakes still there, it was decreased compared to early learning obstacle test. These condition was reinforced after learning with mathematics score school succeed standard $75 \%$ was done.
\end{abstract}

Keywords: Didactical design; Didactical design research; Learning obstacle; Learning trajectory

\section{PENDAHULUAN}

Pembelajaran matematika pada dasarnya berkaitan dengan tiga hal yaitu guru, siswa, dan materi (Suryadi, 2010b). Jika pembelajaran hanya didasarkan atas pemahaman tekstual akan menghasilkan proses belajar matematika yang bersifat miskin makna dan konteks, serta proses belajar berorientasi hasil yang menyebabkan siswa belajar secara pasif. Pembelajaran yang kurang bermakna juga dapat mengakibatkan siswa memahami konsep-konsep matematika secara parsial, yaitu tidak terintegrasi antara konsep yang satu dengan konsep yang lain.

Pemahaman siswa terhadap konsep-konsep matematika secara parsial, dikarenakan buku sumber yang ada atau proses pembelajaran yang tidak terstruktur (learning trajectory), atau keduanya (Suratno, 2012). Contoh kasus yang ditemukan di lapangan pada buku wajib untuk siswa yaitu bagaimana siswa dapat mengaitkan antara konsep luas daerah segitiga yang dibangun dari persegi atau persegipanjang dengan luas daerah segitiga yang bukan siku-siku, serta bagaimana menerapkan luas daerah segitiga untuk menemukan aturan luas daerah segiempat lainnya (Suryadi, 2010a). Kasus lain 
yang tak kalah penting adalah siswa mengalami kesulitan bila dihadapkan pada konteks berbeda.

Brousseau (2002) menyatakan bahwa pada praktiknya, siswa secara alamiah mungkin mengalami situasi yang disebut sebagai kesulitan belajar (learning obstacle) Penyebab kesulitan belajar siswa ada 3 faktor yaitu: hambatan ontogeni (kesiapan mental belajar), didaktis (akibat pengajaran guru), dan epistemologi (pada pengetahuan siswa yang memiliki konteks aplikasi terbatas) (Suryadi, 2013). Berdasarkan hal tersebut, pembelajaran selama ini telah terbentuk hambatan belajar sistemik bagi siswa yaitu siswa hanya sebatas hadir di kelas (siswa tidak belajar). Kenyataan tersebut menyiratkan bahwa seorang guru harus menciptakan situasi belajar bagi siswa agar pembelajaran menjadi bermakna.

Perbaikan proses pembelajaran harus terus dilakukan, salah satunya adalah proses pembelajaran yang dikaitkan dengan kemampuan matematika siswa. Kemampuan matematika siswa secara signifikan meningkat, akan tetapi belum terungkap hambatan psikologinya (Dedy, Mulyana, \& Sudihartinih, 2012; Sumiaty \& Dedy, 2012). Oleh karena itu, dalam rangka memperbaiki proses pembelajaran juga memerlukan pengembangan Lembar Kegiatan Siswa (LKS) berdasarkan hambatan yang dialami siswa. Sebelum mengkaji kebermaknaan pembelajaran di dalam kelas, terlebih dahulu perlu menguji learning obstacle (kesalahan menyelesaikan soal). Selanjutnya membuat bahan ajar untuk memperbaiki learning trajectory (sintak atau struktur penyampaian konsep dalam proses belajar mengajar) berdasarkan temuan pada learning obstacle dan berdasarkan learning trajectory nya.

Adapun masalah dalam penelitian ini yaitu: (1) jenis masalah apa saja yang teridentifikasi selama proses pembelajaran?; (2) kemampuan apa saja yang dapat dimunculkan dari siswa melalui pembelajaran terhadap konsep operasi pada bilangan bulat (khususnya pada sifat operasinya), fungsi, dan kesebangunan pada segitiga?; (3) bagaimana bentuk desain didaktis alternatif (disain didaktis revisi) berdasarkan analisis masalah konsep operasi pada bilangan bulat, fungsi, dan kesebangunan pada segitiga?; dan (4) bagaimana implementasi desain didaktis berdasarkan analisis masalah yang terdapat dalam konsep operasi pada bilangan bulat, fungsi, dan kesebangunan pada segitiga? 
Berdasarkan rumusan masalah tersebut, tujuan dari penelitian ini adalah memperbaiki pembelajaran dengan cara membuat bahan ajar berbasis learning obstacle dan learning trajectory. Penelitian ini sangat penting dilakukan, karena melalui bahan ajar yang dibuat berdasarkan learning obstacle dan learning trajectory, pembelajaran akan bermakna, dan kualitas pembelajaran akan semakin membaik.

\section{METODE PENELITIAN}

Jenis penelitian yang digunakan adalah penelitian desain didaktis (Didactical Design Research) dengan pendekatan kualitatif. Penelitian desain didaktis melalui tiga tahapan analisis, yaitu: (a) Analisis situasi didaktis sebelum pembelajaran yang wujudnya berupa desain didaktis hipotesis termasuk Analisis Didaktis dan Pedagogis (ADP), (b) Analisis metapedadidaktik, yakni analisis kemampuan guru yang meliputi tiga komponen yang terintegrasi yaitu kesatuan, fleksibilitas, dan koherensi dalam pembelajaran, dan (c) Analisis retrosfektif, yakni analisis yang mengaitkan hasil analisis situasi didaktis hipotesis dengan hasil analisis metapedadidaktik.

Tempat penelitian ini dilaksanakan di SMP Percontohan Universitas Pendidikan Indonesia (Laboratorium School UPI). Subjek penelitian ini 2 guru matematika, sedangkan objek penelitian adalah buku matematika SMP kelas VII, VIII, dan kelas IX dengan pokok bahasan operasi pada bilangan bulat, fungsi, dan kesebangunan pada segitiga.

Sebelum melakukan penyusunan desain didaktis awal konsep operasi hitung pada bilangan bulat, fungsi dan kesebangunan pada segitiga, langkah pertama yang dilakukan adalah melakukan uji instrumen untuk mendapatkan learning obstacle pada siswa yang sudah mendapatkan pembelajaran konsep tersebut. Langkah berikutnya yaitu menganalisis learning trajectory, antara lain melakukan analisa buku sumber sebagai pegangan siswa dan guru serta menganalisis video pembelajaran. Berdasarkan Learning obstacle dan learning trajectory yang diperoleh dapat menjadi acuan untuk menyusun suatu desain didaktis awal yang dapat mengatasi kesulitan siswa dalam belajar. Desain didaktis ini juga disesuaikan dengan kompetensi-kompetensi matematika yang relevan.

Setelah itu, desain didaktis awal diimplementasikan pada pembelajaran konsep operasi bilangan di kelas VII SMP Laboratorium School konsep fungsi di kelas VIII SMP Laboratorium School, dan konsep kesebangunan pada segitiga di kelas VIII SMP 
Labortorium School yang belum pernah mendapatkan materi itu sebelumnya. Dampak dari hasil implementasi pembelajaran tersebut dapat menggambarkan learning obstacle. Jika terdapat hal-hal yang kurang sesuai, maka disusunlah sebuah desain didaktis revisi untuk menyempurnakannya.

Fokus penelitian ini yaitu mengkaji learning trajectory berupa alur konsep operasi pada bilangan bulat, fungsi, dan kesebangunan pada segitiga, dan menyusun desain didaktis berdasarkan learning trajectory. Dengan desain didaktis tersebut diharapkan dapat memperbaiki dan mengembangkan proses pembelajaran ke arah yang lebih baik dan mengatasi learning obstacle yang dialami oleh siswa.

Setelah diperoleh data berdasarkan uji learning obstacle, kemudian menganalisa buku paket, menganalisis video pembelajaran, serta menganalisa learning trajectorynya. Selanjutnya dibuat bahan ajar atau disain didaktis awal yang berbasis learning obstacle dan learning trajectory.

Pada tahap ini tim peneliti melakukan diskusi rutin untuk membuat instrumen learning obstacle dari beberapa konsep yang terpilih (esensial) untuk kelas VII, VIII, dan kelas IX. Tahap selanjutnya, setelah dianalisa tentang learning obstacle yang muncul dan berdasarkan dugaan learning trajectory dari setiap konsep yang dipelajari siswa dibuatlah disain didaktisnya. Akhir dari rangkaian panjang diskusi rutin, tim peneliti menyusun semua hasil temuan.

Teknik pengumpulan data yang dilakukan dalam penelitian ini adalah dengan menyatukan data dari hasil pengujian instrumen, observasi (pengamatan), wawancara, dokumentasi, dan studi literatur. Observasi yang dilakukan dengan cara pengamatan dan pencatatan yang dilakukan terhadap objek ditempat berlangsungnya peristiwa sehingga observer berada bersama objek tersebut. Wawancara dilakukan ketika responden mengerjakan instrumen sehingga bisa langsung diketahui letak kesulitan yang dialami responden dalam menyelesaikan soal yang diujikan. Aspek yang digali misalnya proses berpikir dan strategi yang digunakan untuk menjawab soal instrumen. Teknik wawancara yang dilakukan adalah wawancara tidak berstruktur dan bersifat informal sehingga lebih fleksibel.

\section{HASIL DAN PEMBAHASAN}

Berikut disajikan hasil penelitian sekaligus pembahasan lengkap mengenai penelitian tersebut. 


\section{Analisis Learning Obstacle Konsep Operasi pada Bilangan Bulat}

Temuan yang diperoleh dalam menganalisis learning obstacle konsep operasi pada bilangan bulat khususnya sifat distributif bilangan bulat, secara umum hambatan epistimologis siswa tergolong ke dalam 4 tipe. Learning obstacle tipe 1 berkaitan dengan concept image siswa. Hal ini terjadi karena siswa cenderung mengalami kesulitan terkait pemahaman sifat distributif pada operasi bilangan bulat. Learning obstacle tipe 2 berkaitan dengan pemahaman urutan operasi campuran pada bilangan bulat. Learning obstacle tipe 3 berkaitan dengan kemampuan pemahaman siswa tentang arti 'selisih', dan learning obstacle tipe 4 berkaitan dengan koneksi konsep operasi bilangan bulat dengan kehidupan sehari-hari.

Pada hasil penelitian ini didapatkan bahwa mayoritas siswa sudah mampu menyelesaikan soal dengan menggunakan sifat distributif. Akan tetapi ada beberapa siswa yang tidak menggunakan sifat distributif, namun mereka tahu bahwa ada operasioperasi yang harus didahulukan dalam menyelesaikan soal ini yaitu operasi perkalian terlebih dahulu kemudian penjumlahan.

Jika dibandingkan dengan learning obstacle awal yaitu mengenai kemampuan siswa terkait pemahaman operasi campuran pada bilangan bulat maka didapatkan bahwa kesulitan siswa setelah implementasi desain didaktis sudah tidak banyak muncul lagi. Tercatat hanya beberapa siswa yang melakukan kesalahan karena beberapa faktor.

Kemampuan pemahaman siswa terkait arti 'selisih' pada operasi bilangan bulat didapatkan bahwa hampir semua siswa yaitu sekitar 90\% mengerti arti 'selisih'. Sehingga siswa mampu menyelesaikan soal yang berkaitan dengan operasi selsisih dengan baik dan benar. Sedangkan kemampuan pemahaman siswa dalam mengoneksikan operasi bilangan bulat dengan kehidupan sehari-hari, didapatkan bahwa hampir seluruh siswa (sekitar 96,67\%) mampu menyelesaikan soal ini dengan baik dan benar. Siswa mampu memahami maksud soal dengan baik dan mampu menggunakan konsep bilangan bulat dalam menyelesaikan soal ini dengan baik pula.

\section{Analisis Learning Obstacle Konsep Fungsi}

Temuan hasil analisis learning obstacle yang terkait dengan konsep fungsi yaitu secara umum hambatan epistimologis siswa tergolong ke dalam 4 tipe. Learning obstacle tipe 1 berkaitan dengan concept image siswa. Hal ini terjadi karena siswa cenderung mengalami kesulitan mengenali bentuk fungsi baik yang disajikan dalam 
diagram cartesius maupun himpunan pasangan berurutan. Learning obstacle tipe 2 berkaitan dengan kemampuan komunikasi siswa dalam menyajikan fungsi ke dalam tiga bentuk (diagram panah, himpunan pasangan berurutan, dan koordinat cartesius). Learning obstacle tipe 3 berkaitan dengan aturan penamaan fungsi dan learning obstacle tipe 4 berkaitan dengan aplikasi fungsi.

Masalah yang muncul saat uji learning obstacles awal adalah siswa tidak dapat memberikan alasan mengenai situasi yang ada dalam soal fungsi atau bukan fungsi. Setelah bahan ajar yang telah dibuat dalam penelitian ini diimplementasikan kepada siswa kelas 8 didapatkan bahwa siswa mampu mengatasi permasalahan ini. Berdasarkan hasil implementasi didapatkan bahwa sebanyak 24 dari 27 siswa dapat menjawab soal ini dengan benar. Tiga orang yang belum tepat menjawab pertanyaan ini adalah siswa yang tidak hadir pada saat proses pembelajaran mengenai konsep awal fungsi.

Sama halnya dengan jawaban siswa pada saat uji learning obstacle awal, hampir seluruh siswa mengilustrasikan situasi ini ke dalam diagram panah. Hal ini berarti bahwa diagram panah merupakan diagram yang paling mudah bagi siswa untuk membedakan relasi yang merupakan fungsi atau bukan fungsi.

Pada saat uji learning obstacle awal didapatkan bahwa masih sedikit siswa yang dapat menyajikan situasi yang diberikan dalam diagram panah, himpunan pasangan berurut, dan diagram cartesius. Setelah dilakukan implementasi bahan ajar penelitian ini kepada siswa kelas 8 didapatkan bahwa kekeliruan yang muncul pada saat uji learning obstacle awal dapat teratasi. Hal ini terlihat dari banyaknya siswa yang dapat menyajikan situasi yang diberikan dalam diagram panah, himpunan pasangan berurut, dan diagram cartesius.

Tiga orang siswa yang tidak masuk saat materi konsep awal fungsi, dapat menyatakan situasi yang diberikan ke dalam diagram panah, himpunan pasangan berurut, dan diagram cartesius. Hal tersebut bisa terjadi dikarenakan pada saat proses pembelajaran materi relasi, guru model menyajikan relasi bukan hanya dalam diagram panah, tetapi juga dalam himpunan pasangan berurut dan juga diagram cartesius, sehingga kekeliruan yang muncul saat uji learning obstacle awal dapat teratasi.

Kesulitan siswa saat menyelesaikan soal tersebut adalah menerapkan konsep aljabar yang telah mereka pelajari di kelas 7. Pada saat implementasi bahan ajar, guru model kurang menekankan mengenai konsep aljabar kepada siswa di bagian apersepsi. 
Oleh karena itu, pada saat proses pembelajaran materi aturan fungsi, apersepsi mengenai konsep aljabar sangat perlu ditekankan. Hasil jawaban siswa ini menunjukkan bahwa masih ada siswa yang keliru dalam konsep aljabar. Namun, secara konsep aturan fungsi sudah cukup mereka pahami.

Agar kekeliruan tidak terjadi lagi seperti di atas, nampaknya diperlukan pertemuan tambahan mengenai aturan fungsi yang lebih mendalam sehingga kekeliruan seperti di atas tidak terjadi lagi. Selain itu, konsep aljabar yang telah dipelajari siswa di kelas 7 perlu untuk diingatkan kembali sebelum memasuki konsep aturan fungsi.

Uji learning obstacle awal menunjukan bahwa banyak siswa tidak dapat membedakan relasi yang merupakan fungsi dan bukan fungsi yang disajikan melalui diagram cartesius. Setelah implementasi bahan ajar dalam penelitian ini didapatkan bahwa siswa dapat membedakan relasi yang merupakan fungsi dan bukan fungsi yang disajikan dalam diagram cartesius ataupun diagram panah. Hampir seluruh siswa dapat membedakan relasi yang merupakan fungsi dan bukan fungsi yang disajikan dalam himpunan pasangan berurut.

\section{Analisis Learning Obstacle Konsep Kesebangunan pada Segitiga}

Hasil analisis learning obstacle konsep kesebangunan pada segitiga yaitu ternyata hampir seluruh siswa mengalami kesulitan dalam memahami konsep kesebangunan. Hal ini terjadi karena ketika pembelajaran di dalam kelas siswa tidak memaknai dengan sungguh-sungguh tentang konsep kesebangunan. Biasanya, siswa juga lebih sering belajar meniru contoh-contoh yang sudah ada, bukan memahami secara utuh ataupun mengkonstruksi sebuah konsep hasil dari pemikiran sendiri, sehingga ketika mendapatkan soal yang berbeda dari contoh, siswa malah tidak dapat menyelesaikannya dengan baik. Berdasarkan hasil tersebut maka pembelajaran kesebangunan dua buah segitiga harus diperbaiki, terutama konsep sudut dan sisi pada segitiga karena masih ada siswa yang keliru memahaminya. Oleh karena itu, untuk memperbaiki proses pembelajaran kesebangunan dua buah segitiga maka disusunlah sebuah desain didaktis konsep kesebangunan dua buah segitiga yang diimplementasikan di kelas IX.

Berdasarkan temuan di atas, maka secara umum hambatan epistimologis siswa tergolong ke dalam beberapa tipe. Learning obstacle tipe 1 berkaitan dengan concept image, siswa cenderung mengalami kesulitan mengenali kesamaan ukuran dari pasangan sudut yang bersesuaian pada dua buah segitiga yang sebangun (termasuk 
aturan penamaan dua buah segitiga sebangun). Learning obstacle tipe 2 berkaitan dengan kemampuan komunikasi siswa dalam memahami kesebangunan dari dua segitiga dengan variasi letak segitiga yang sedikit berbeda. Learning obstacle tipe 3 berkaitan dengan kemampuan siswa dalam menyelesaikan masalah sehari-hari yang berkaitan dengan konsep kesebangunan.

Pada hasil penelitian ini didapatkan bahwa siswa sudah memahami konsep kesebangunan dua buah segitiga. Konsep dari segitiga-segitiga yang sebangun yaitu sisi-sisi yang bersesuaian sebanding dan sudut-sudut yang bersesuaiannya sama besar. Banyaknya pasangan sudut yang sehadap memang hanya dua pasang. Sebenarnya, hanya dengan menyatakan ada dua pasang sudut yang bersesuaian berukuran sama besar pada dua buah segitiga, itu sudah cukup memenuhi syarat kesebangunan dua buah segitiga. Hal ini sesuai dengan teorema kesebangunan sudut-sudut (sd-sd) yang berbunyi diketahui korespondensi di antara dua segitiga, jika dua pasang sudut yang saling berkorespondensi (bersesuaian) kongruen (sama besar), maka korespondensi itu suatu kesebangunan.

Berdasarkan hasil yang diperoleh, ternyata sebagian besar siswa sudah memahami konsep dua segitiga yang sebangun serta mampu memberikan alasan dengan tepat berdasarkan syarat-syarat kesebangunan. Siswa juga mampu menyelesaikan soal penghitungan dengan jawaban yang tepat meskipun masih terdapat siswa yang memberikan jawaban yang tidak tepat.

Selain hasil penelitian di atas, didapatkan pula hampir seluruh siswa mengalami kesulitan dalam menjawab pertanyaan "apakah kedua segitiga tersebut sebangun atau tidak dan alasan apa yang menyebabkan segitiga tersebut sebangun?". Hal ini terjadi karena siswa masih terbiasa mengerjakan soal prosedural seperti kasus-kasus sebelumnya. Jadi, setelah pembelajaran ini learning obstacle yang sebelumnya ada sudah berkurang, bahkan berkurang secara drastis, meskipun masih ada beberapa siswa yang belum memahami konsep secara utuh.

Berdasarkan hasil kajian di atas, menunjukkan bahwa kesalahan yang dilakukan siswa masih ada tetapi sudah jauh berkurang dibanding hasil temuan pada saat uji learning obstacle awal. Dengan demikian bila pembelajaran dilakukan dengan sarat makna dan melayani siswa untuk belajar salah satunya dengan membuat bahan ajar atau disain didaktis yang berlandaskan kesalahan-kesalahan yang telah dilakukan siswa yang 
telah mempelajari materi tersebut serta berdasarkan kesalahan sistematika atau sintak membelajarkan siswa (baik melalui video pembelajaran ataupun melalui analisa buku sumber), akan memberikan dampak yang sangat signifikan bagi kualitas pembelajaran. Kondisi ini diperkuat dengan hasil tes learning obstacle setelah pembelajaran, baik untuk konsep operasi hitung bilangan bulat, konsep fungsi, maupun konsep kesebangunan segitiga menunjukkan bahwa secara kelompok dengan standar ketuntasan sekolah (minimal nilai matematika 75\%) sudah tuntas.

\section{Analisis Buku Pegangan Siswa}

Terdapat beberapa temuan terkait konsep operasi bilangan bulat pada buku pegangan siswa. Kesalahan tersebut antara lain: (a) kesalahan pengetikan, (b) pengertian tanda “+” dan "-" (sebagai operasi atau sebagai tanda bilangan) yang tidak jelas, sehingga penggunaan alat peraga garis bilangan tidak membantu siswa untuk memahami dengan baik konsep operasi bilangan bulat, dan (c) tujuan penggunaan alat peraga yang tidak jelas (pengoperasian dua bilangan bulat yang besar masih menggunakan alat peraga).

Terdapat beberapa temuan terkait konsep fungsi pada buku pegangan siswa. Kesalahan tersebut antara lain: (a) kegiatan menanamkan pengertian fungsi yang tidak bermakna; (b) urutan penyajian fungsi sebaiknya adalah diagram panah, diagram cartesius, himpunan pasangan berurut, rumus fungsi, tabel, dan grafik; (c) grafik penyajian fungsi keliru, seharusnya hanya berupa titik-titik (bukan berupa garis lurus) karena domain dan kodomain fungsi diketahui bilangan asli bukan bilangan real; dan (d) ada soal yang menginstruksikan siswa untuk menyajikan fungsi dengan kodomainnya berupa himpunan bilangan real, padahal bilangan real belum dikenalkan kepada siswa sebelumnya.

Terdapat beberapa temuan terkait konsep kesebangunan bangun datar segitiga pada buku pegangan siswa. Kesalahan tersebut antara lain: (a) urutan materi tidak terurut dari materi esensial ke materi lanjutan; (b) siswa dapat mengalami kebingungan, karena konsep kesebangunan dimulai dari bangun datar segiempat (sebaiknya dimulai dari bangun datar yang lebih sederhana yaitu bangun datar segitiga); dan (c) siswa akan mengalami kesulitan dalam menyelesaikan soal-soal pemecahan masalah, karena hanya terbiasa dengan soal-soal yang rutin dan menuntun siswa untuk berpikir secara mekanis serta kurang mengarah kepada penguasaan kemampuan penerapan (aplikatif). 


\section{Analisis Video Pembelajaran}

Video pembelajaran yang dianalisis dalam penelitian ini mengenai konsep fungsi. Adapun deskripsi pembelajarannya adalah sebagai berikut:

\section{Guru Model 1}

Di dalam video disajikan suatu proses pembelajaran mengenai relasi dan fungsi. Proses pembelajaran dimulai dengan pengenalan konsep relasi secara kontekstual lalu menuju konsep yang lebih abstrak. Relasi yang dikenalkan di awal pembelajaran hanya dalam diagram panah saja. Setelah itu, siswa diinstruksikan untuk membedakan relasi yang merupakan fungsi dan bukan fungsi.

Pada saat proses pembelajaran terkait membedakan relasi dan fungsi, siswa hanya dikenalkan relasi dan fungsi yang disajikan dalam diagram panah. Apabila siswa diinstruksikan untuk membedakan relasi dan fungsi dalam himpunan pasangan berurut dan diagram panah, maka siswa akan mengalami kesulitan walaupun siswa sudah memahami syarat suatu fungsi. Hal itu terjadi karena siswa belum dikenalkan untuk menyajikan relasi dalam himpunan pasangan berurut dan diagram cartesius. Oleh karena itu, akan lebih baik sebelum masuk ke dalam konsep fungsi, siswa sebaiknya dikenalkan terlebih dahulu untuk menyajikan relasi ke dalam himpunan pasangan berurut dan diagram cartesius.

\section{Guru Model 2}

Di dalam video disajikan suatu proses pembelajaran mengenai relasi dan fungsi. Proses pembelajaran dimulai dengan pengenalan konsep relasi secara kontekstual lalu menuju konsep yang lebih abstrak. Untuk relasi mengenai "ukuran sepatu", guru memulai apersepsi dengan bertanya kepada siswa, "Apakah mungkin seseorang yang berukuran sepatu 35 menggunakan sepatu yang berukuran 39?" Jawaban dari pertanyaan tersebut adalah tentu saja bisa. Namun, guru model 2 menyangkalnya dengan mengatakan bahwa seseorang yang berukuran sepatu 35 harus menggunakan sepatu nomor 35 .

Secara logika sederhana, seseorang yang mempunyai ukuran sepatu berukuran 35 pasti bisa menggunakan sepatu berukuran 39, namun tidak berlaku sebaliknya. Berdasarkan kondisi di atas, alangkah baiknya relasi "ukuran sepatu" jangan digunakan dalam membedakan konsep relasi dan fungsi karena dikhawatirkan dapat menimbulkan keambiguan makna. 
Dalam video ini, penarikan kesimpulan dalam aturan fungsi dilakukan oleh guru. Sebaiknya penarikan kesimpulan dilakukan oleh siswa sedangkan guru berperan dalam bagian konfirmasinya.

\section{SIMPULAN DAN SARAN}

Jenis masalah yang teridentifikasi selama proses pembelajaran baik untuk konsep operasi bilangan bulat, konsep fungsi, maupun konsep kesebangunan adalah learning obstacle terkait konsep image, learning obstacle terkait komunikasi, serta learning obstacle terkait koneksi. Kemampuan siswa yang dapat dimunculkan melalui pembelajaran sifat operasi bilangan bulat adalah kemampuan menyelesaikan masalah berdasarkan kekuatan operasi, kemampuan memanfaatkan sifat operasi (sifat distributif), dan kemampuan membuat model matematika dari masalah kontekstual dalam kehidupan sehari-hari dan menyelesaikannya melalui sifat distributif. Kemampuan siswa yang dapat dimunculkan melalui pembelajaran konsep fungsi yaitu kemampuan menjelaskan pengertian fungsi, kemampuan membedakan fungsi dan bukan fungsi, kemampuan membedakan suatu relasi yang termasuk fungsi dan bukan fungsi, kemampuan menuliskan atau mencari aturan fungsi, serta dapat menyajikan fungsi ke dalam berbagai cara (diagram panah, pasangan terurut, dan grafik), dan kemampuan menggunakan konsep fungsi untuk menyelesaikan permasahan dalam kehidupan sehari-hari.

Kemampuan siswa yang dapat dimunculkan melalui pembelajaran konsep kesebangunan dua buah segitiga adalah kemampuan mengungkapkan pengertian dua buah segitiga sebangun melalui sifat-sifatnya, kemampuan mengaitkan prasyarat (bila dua garis sejajar dipotong oleh sebuah garis maka akan terbentuk sudut sehadap, sudut bertolak belakang sama besar, dan sudut berimpit sama besar) dengan dua buah segitiga sebangun, kemampuan mengidentifikasi dua buah segitiga itu sebangun atau tidak, kemampuan menentukan panjang salah satu sisi sebuah segitiga melalui konsep kesebangunan dikaitkan dengan dalil Pythagoras, kemampuan mengilustrasikan suatu permasalahan ke dalam bentuk geometri, serta kemampuan mengaplikasikan konsep kesebangunan dua buah segitiga dalam kehidupan sehari-hari.

Berdasarkan temuan penelitian di lapangan, ada beberapa saran yang harus dilakukan oleh guru sebelum implementasi pembelajaran: (1) Membuat LKS terlebih 
dahulu, selain berbasis karakter materi juga berbasis hambatan siswa antara lain melalui learning obstacle saat merancang situasi didaktis, dan (2) Guru perlu memikirkan prediksi respon siswa atas situasi tersebut serta antisipasinya sehingga tercipta situasi didaktis baru dan learning trajectory.

\section{DAFTAR RUJUKAN}

Brousseau, G. (2002). Theory of didactical situation in mathematics (Vol. 19). New York: Kluwer Academic Publishers.

Dedy, E., Mulyana, E., \& Sudihartinih, E. (2012). Pengembangan bahan ajar kalkulus vektor berdasarkan model pembelajaran matematika Knisley sebagai upaya meningkatkan kompetensi matematika mahasiswa. Pythagoras: Jurnal Pendidikan Matematika, 7(1), 101-112.

Sumiaty, E. \& Dedy, E. (2012). Pembelajaran berbasis masalah (PBL) dengan pendekatan problem possing melalui lesson study di SMP LabSchool UPI untuk meningkatkan kemampuan berpikir kritis matematika siswa. Bandung: FPMIPA UPI.

Suratno, T. (2009). Memahami kompleksitas pengajaran-pembelajaran dan kondisi pendidikan dan pekerjaan guru. Tersedia: http://the2the. com/eunica/document/TSuratno_complex_syndrome.pdf [18 Mei 2013].

Suryadi, D. (2010a). Metapedadidaktik dan didactical design research (DDR): Sintesis hasil pemikiran berdasarkan lesson study. dalam teori, paradigma, prinsip, dan pendekatan pembelajaran MIPA dalam konteks Indonesia. Bandung: FPMIPA UPI.

Suryadi, D. (2010b). Menciptakan proses belajar aktif: Kajian dari sudut pandang teori belajar dan teori didaktik. Tersedia: http://didi-suryadi.staf.upi.edu/files/2011/06/ MENCIPTAKAN-PROSES-BELAJAR-AKTIF.pdf [13 November 2012].

Suryadi, D. (2013). Didactical design research (DDR) to improve the teaching of mathematics. Far East Journal of Mathematical Education, 10(1), 91-107. 